\title{
Erratum to: Relationships among time orientation, consumer innovativeness, and innovative behavior: the moderating role of product characteristics
}

\author{
Kiran Karande • Altaf Merchant • K. Sivakumar
}

Received: 7 December 2010 / Accepted: 1 June 2011 / Published online: 2 August 2011

(C) Academy of Marketing Science 2011

\section{Erratum to: AMS Review \\ DOI 10.1007/s13162-011-0008-Z}

\begin{abstract}
Consumer innovativeness is a critical factor that determines the success of new product introductions. An important but underexplored antecedent of consumer innovativeness is time orientation. In this article, we propose a conceptual model of the relationships among time orientation, consumer innovativeness, and consumer innovative behavior. We further examine the moderating role of several important product characteristics on these
\end{abstract}

Due to errors introduced during the production process, we are republishing the entire article in its corrected format. The online version of the original article can be found at http://dx.doi.org/ 10.1007/s13162-011-0008-z.

The authors greatly appreciate the guidance of co-editors Victoria Crittenden and Robert Peterson, and the constructive comments of the reviewers during the review process. They are also grateful for the useful comments from Ronald Goldsmith, Subin Im, Donald Lehmann, and Nancy Wong on a previous draft of the manuscript.

\section{K. Karande}

Old Dominion University,

Norfolk, VA, USA

e-mail:kkarande@odu.edu

\author{
A. Merchant \\ University of Washington Tacoma, \\ Tacoma, WA, USA \\ e-mail: altafm@u.washington.edu \\ K. Sivakumar $(\bowtie)$ \\ Lehigh University, \\ Bethlehem, PA, USA \\ e-mail: k.sivakumar@lehigh.edu
}

relationships. These characteristics include (1) newness of the product, (2) product complexity, (3) network externalities, and (4) the utilitarian versus expressive nature of the product. We develop a series of research propositions to explicate the relationships in our conceptual model. We delineate the substantive and managerial implications by linking the variables through a comprehensive framework and provide future research directions.

Keywords Consumer innovativeness - Time orientation . Innovative behavior Product characteristics

\section{Introduction}

New products are a major source of success and prosperity for companies. Cooper et al. (2001) argue that the future belongs to companies that can succeed with new products and that firms that are not able to do so will inevitably vanish. Therefore, corporations spend millions of dollars introducing new products in the marketplace. Ironically, not all new products perform well. In a research study involving 413 companies, Barczak et al. (2009) find that only $59 \%$ of new products launched are considered successful. Similarly, Martin (2008) finds that of the new products that survive the first year of launch, only a handful are adopted by consumers or have any meaningful impact on the company's long-term profitability. Therefore, enhancing the understanding of the factors that influence the adoption of new products is of considerable significance to academic researchers and marketing practitioners alike. 
In their influential conceptual model on new product diffusion, Gatignon and Robertson (1985) discuss the importance of examining both consumer characteristics and new product attributes (among other variables) to gain a better understanding of the new product adoption process. Research has shown that consumer innovativeness plays an important role in determining whether consumers will try a new product or service (e.g., Vandecasteele and Geuens 2010; Steenkamp and Gielens 2003; Goldsmith 2001; Goldsmith et al. 1995).

Consumer innovativeness involves proclivity for change owing to cognitive processing, such as evaluating the risks, costs, and benefits of adopting innovations, and emotional reasons, such as anticipated pleasure from purchasing new products (Bartels and Reinders 2010). These characteristics of consumer innovativeness overlap with the consumer's past (comfort in old ways of working), present (focusing on enjoying the moment), and future (sacrificing present pleasures for future) time orientations (Cotte et al. 2004; Zimbardo and Boyd 1999; Bergadaa 1990).

Consumers' predominant time orientations are fundamental to their personality and mold all aspects of their attitudes and behaviors (Zimbardo and Boyd 1999; Gonzalez and Zimbardo 1985). Time orientation plays a leading-connective role in the relationship between personal and social experiences and helps give meaning and order to everyday life events; thus, time orientation exerts a dynamic influence on judgment, decision, and actions (D'Alessio et al. 2003; Zimbardo et al. 1997). In the marketing literature, consumers' time orientations have also been shown to have a bearing on their shopping behaviors (Cotte et al. 2004) and their preference for and consumption of goods and services (Braun-Latour et al. 2007; Bergadaa 1990).

Given the similarity in the characteristics of consumer innovativeness and the three time orientations and literature relating time orientations to consumer behavior, it is noteworthy that the three time orientations have not been investigated as antecedents of consumer innovativeness. Although Steenkamp et al. (1999) link consumers' nostalgia proneness to their innovativeness, to our knowledge, no study has investigated present and future orientations as antecedents of consumer innovativeness. Therefore, the first objective of this research is to fill this void in the literature by examining the impact of past, present, and future time orientations on consumer innovativeness.

In an extensive review of the consumer innovativeness scales, Roehrich (2004) calls for additional research explicating the characteristics of the new product while studying consumer innovativeness. In response to this call, our study proposes a moderating role for new product characteristics in the relationship between the three time orientations and consumer innovativeness. The specific characteristics of the new product studied here include (1) newness of the product (i.e., radical versus incremental), (2) product complexity (i.e., complex versus simple), (3) network externalities of the product (i.e., present versus absent), and (4) utilitarian versus expressive nature of product. Several researchers have delineated the prominent effects of product characteristics on consumer innovativeness (e.g., Hoffman and Soyez 2010; Hirunyawipida and Paswan 2006; Paswan and Troy 2005). However, their moderating influence in the time orientation-consumer innovativeness link has yet to be investigated. Thus, the second objective of this study is to obtain additional insights into the link between time orientation and consumer innovativeness by investigating how the four product characteristics moderate this relationship.

Goldsmith et al. (1995) argue that innovative behavior is the most concrete manifestation of consumer innovativeness. Many studies have found a relationship between consumer innovativeness and innovative behavior (e.g., Steenkamp and Van Trijp 1996; Goldsmith et al. 1995). However, no study has investigated whether this relationship varies by product characteristics. Thus, our third objective is to investigate differences in the consumer innovativeness-innovative behavior relationship based on the new product's characteristics.

An examination of the role of product characteristics in the consumer innovativeness-innovative behavior relationship is vital because, according to attitude literature (e.g., theory of planned behavior; Ajzen 1991) attitudes do not necessarily lead to behavior. For example, people may hold positive attitudes toward health foods but have unhealthful food habits; others may have positive attitudes toward a clean environment but exhibit few behaviors that help keep the environment clean. By applying the theory of planned behavior (Ajzen 1991), we investigate the extent to which consumer innovativeness influences innovative behavior and, more specifically, how new product characteristics moderate this link.

To summarize, our research has three objectives:

1) To examine the relationship between past, present, and future time orientations and consumer innovativeness;

2) To examine how newness of the product, product complexity, network externality of the product, and expressive/utilitarian nature of the product moderate the link between time orientations and consumer innovativeness; and

3) To examine how newness of the product, product complexity, network externality of the product, and expressive/utilitarian nature of the product moderate the link between consumer innovativeness and innovative behavior.

We organize this article as follows: We first introduce our conceptual model and describe the various constructs in our framework. We then develop a series of research propositions 


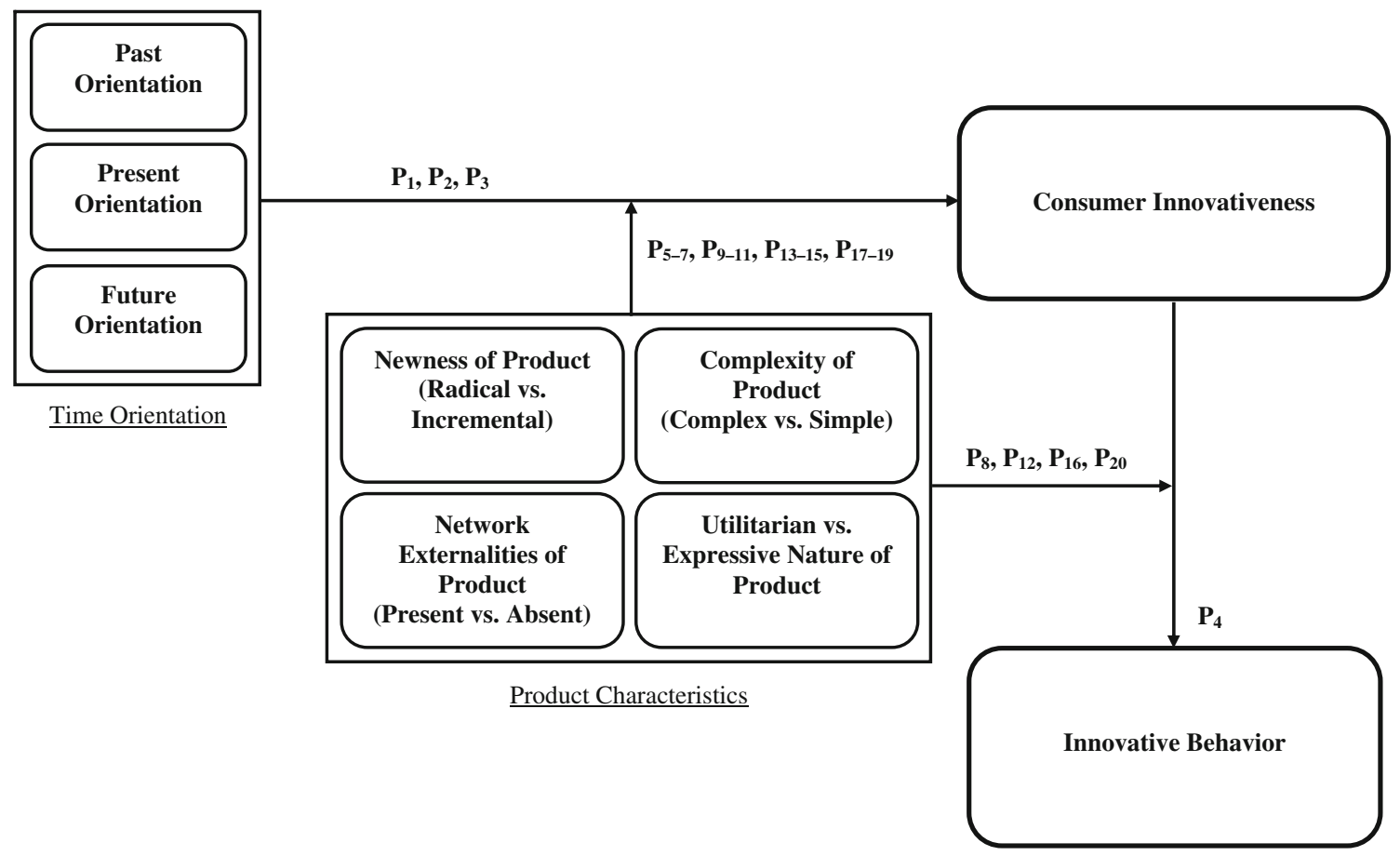

Fig. 1 A model of time orientation, consumer innovativeness, innovative behavior, and product characteristics

that link the various constructs in the model. Next, we describe the theoretical and managerial implications of our framework and propositions. Finally, we present directions for future exploration in this important and exciting domain.

\section{Conceptual framework}

As Fig. 1 shows, the major constructs in the model are (1) past orientation, (2) present orientation, (3) future orientation, (4) consumer innovativeness, (5) innovative behavior, (6) newness of the product, (7) complexity of the product, (8) network externalities of the product, and (9) utilitarian versus expressive nature of the product. Table 1 describes the definitions of each construct. In this section, we define and provide background on each of the constructs in the model. In the following section, we develop our research propositions delineating the relationships we expect among these constructs.

Consistent with the existing literature, we conceptualize that time orientation has three dimensions: past, present, and future. For expositional purposes and in the interest of parsimony, the three dimensions of time orientation are considered separately in our discussion. While we treat the three time orientation constructs as orthogonal, they can be visualized to represent points on a continuum together or in some two-way combination (e.g., past and present, present and future, past and future). Similarly, our propositions are applicable whether each of the time orientations is considered as a categorical variable (e.g., someone is present oriented or not) or as a continuous variable (e.g., someone is more present oriented than someone else).

\section{Past orientation}

Past orientation is defined as a "warm, sentimental attitude towards the past" (Zimbardo and Boyd 1999, p. 1275). People with a high past orientation become sentimental when they think of the past, are prone to nostalgia, and are happy in their set ways of doing things (Zimbardo and Boyd 1999; Holbrook 1993). Past-oriented people act and decide in response to recurrent situations of their past experiences. These people do not take chances and tend to be conservative. A positive feature of past-oriented people is their sense of personal continuity along with a stable sense of self through the years (D'Alessio et al. 2003). If they had positive experiences in the past, they rejoice in recalling them despite their present unhappiness (if any). If they had negative experiences in the past, these too affect their present life (Zimbardo and Boyd 1999).

\section{Present orientation}

Present orientation is defined as "being focused upon immediate events in themselves and diminished concern for, or interest in, future consequences" (Harber et al. 2003, p. 256). People with a high degree of present orientation live for the moment and therefore are "less likely to ponder potential costs and consequent costs or to ruminate over 


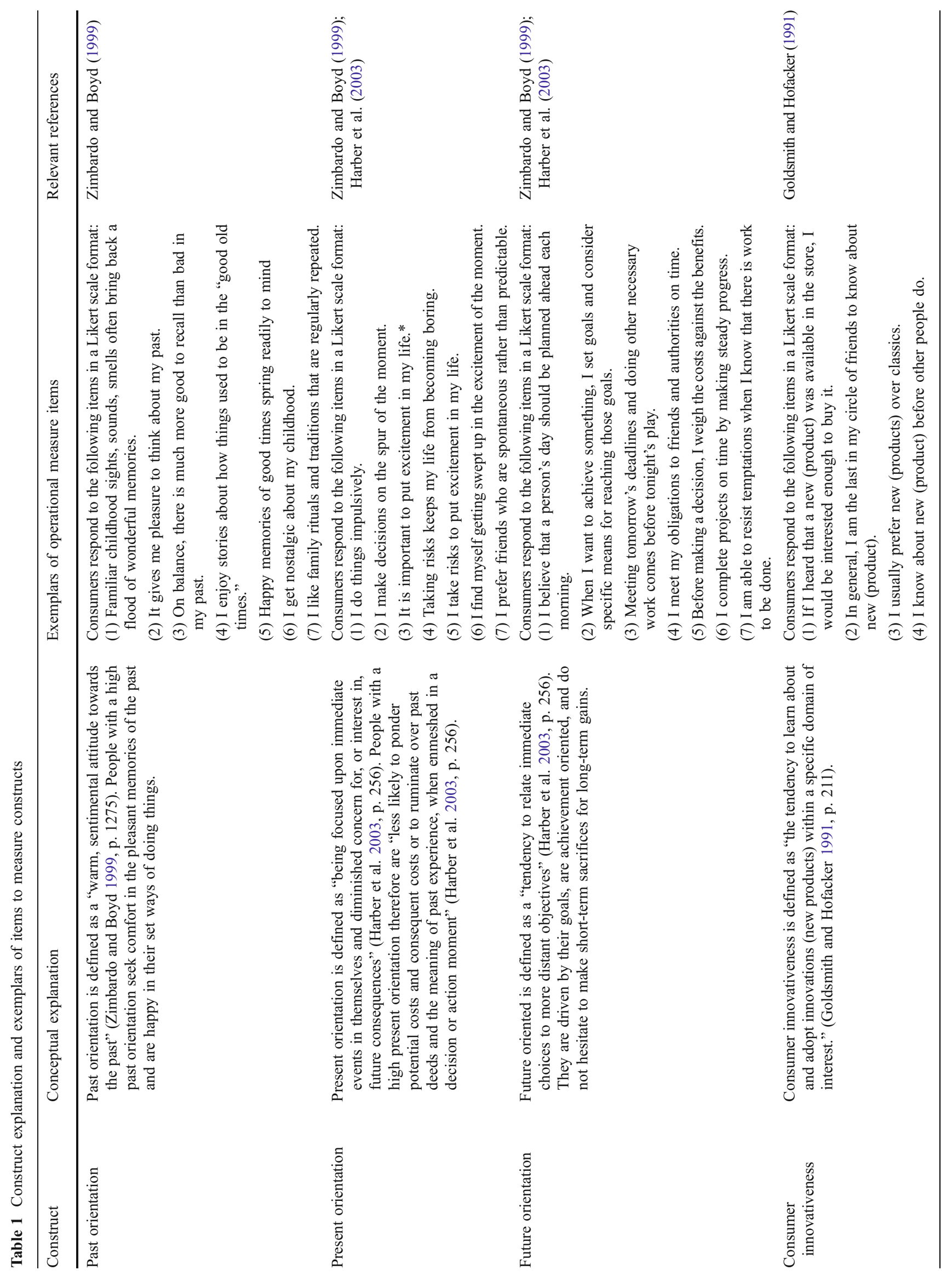




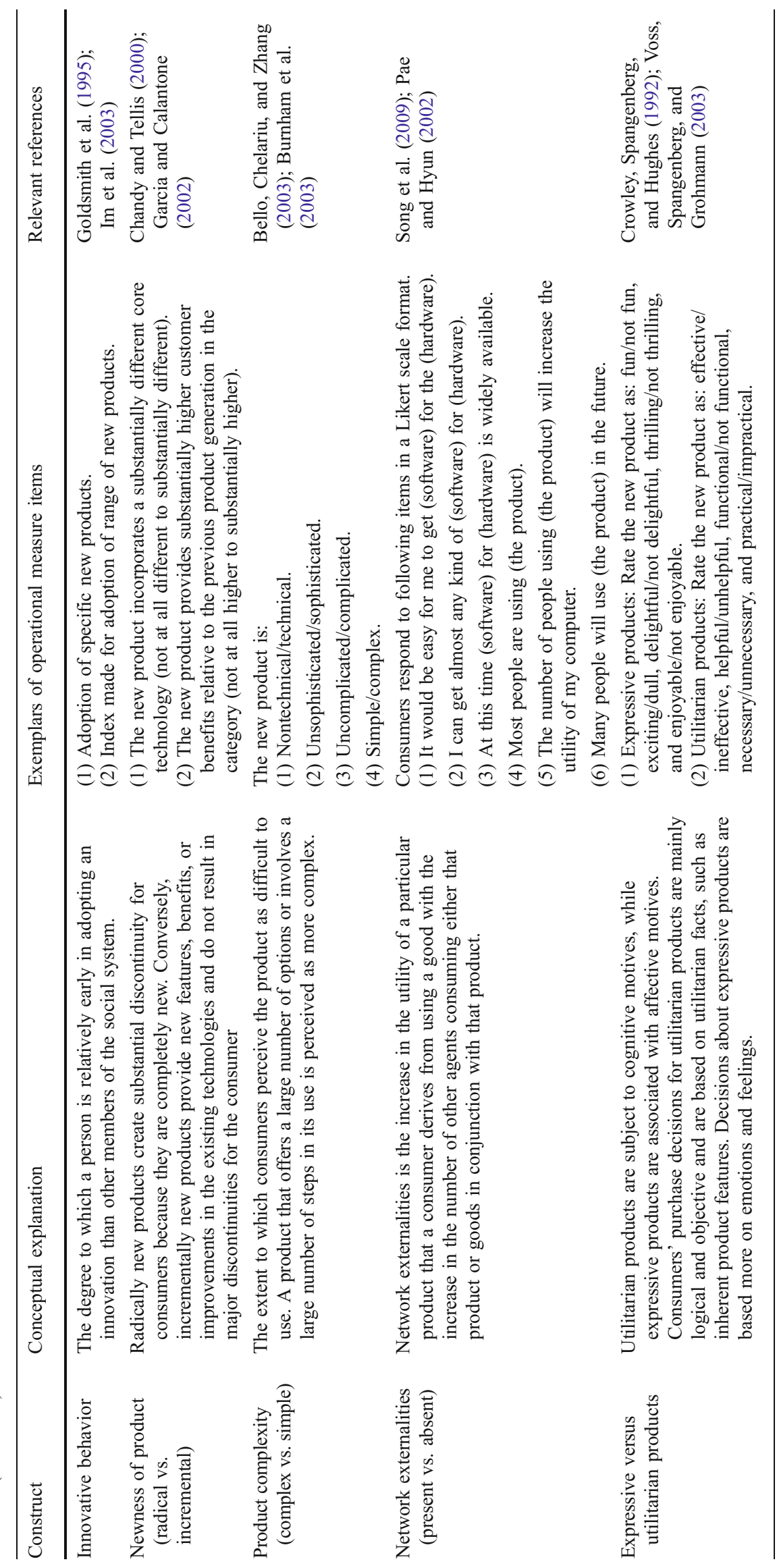


past deeds and the meaning of past experience, when enmeshed in a decision or action moment" (Harber et al. 2003, p. 256). They like to enjoy life in the present (Bergadaa 1990) and become engrossed in the thrill of the moment, focusing on short-term gratifications (Murrell and Mingrone 1994). Dominant present orientation has been related to many negative consequences for people, including mental health problems, juvenile delinquency, addictions, and crime (e.g., Keough et al. 1999; Levine 1997). People with a high degree of present orientation are hedonistic, with a strong desire for instant gratification and taking risks (Murrell and Mingrone 1994; Bergadaa 1990).

Future orientation

Future orientation is defined as a "tendency to relate immediate choices to more distant objectives" (Harber et al. 2003, p. 256). Future-oriented people live for the future. They are driven by their goals, are achievement oriented, and do not hesitate to make short-term sacrifices for long-term gains (Murrell and Mingrone 1994; Strathman et al. 1994). Future orientation is related to positive consequences for people, including higher socio-economic status, superior academic achievement, and fewer risktaking behaviors (e.g., Nuttin 1985; De Volder and Lens 1982).

\section{Consumer innovativeness}

The extant literature has proposed two attitudinal conceptualizations of consumer innovativeness: innate innovativeness and domain-specific innovativeness. The first conceptualization treats innovativeness as an innate personality trait (Baumgartner and Steenkamp 1996). Im, Mason, and Houston (2007, p. 64) define innate consumer innovativeness as "a generalized unobservable trait that reflects a person's inherently innovative personality, predisposition, and cognitive style and can therefore be applied to multiple situations." This conceptualization is also referred to as global innovativeness (Goldsmith and Foxall 2003) and dispositional innovativeness, or the "predisposition to buy new and different products and brands" (Steenkamp et al. 1999, p. 56).

The second conceptualization of innovativeness pertains to a specific domain, or product category, called domainspecific innovativeness. Goldsmith and Hofacker (1991) argue that the conceptualization of "innate" innovativeness does not take into consideration the domain or product area to which the consumer is exposed. For example, a consumer may exhibit greater innovativeness toward music than toward food products, and vice versa. Goldsmith and Hofacker $(1991$, p. 211) note that domain-specific innovativeness "reflects the tendency to learn about and adopt innovations (new products) within a specific domain of interest." They also argue that there is little, if any, overlap of innovativeness across domains or product categories. Therefore, they conclude that "measuring global, innate innovativeness may be of little value to researchers" ( $p$. 210). In line with the arguments in favor of studying consumer innovativeness in the context of the product domain, we use domain-specific innovativeness as the appropriate definition of consumer innovativeness in our framework.

Innovative behavior

Using a behavioral perspective, Rogers and Shoemaker (1971, p. 27) define innovative behavior as "the degree to which an individual is relatively early in adopting an innovation than other members of his social system." Innovative behavior can also be conceptualized as new product adoption behavior and actualized innovativeness (Im et al. 2007). Prior research has operationalized innovative behavior in three ways. First, innovative behavior has been measured by the consumer's time of adoption of a specific new product relative to the adoption times of other consumers (Rogers and Shoemaker 1971). Second, it has been measured by the ownership of a list of new products ( $\mathrm{Im}$ et al. 2003, 2007; Goldsmith et al. 1995). Third, it has been measured by the consumer's purchase intentions (Holak and Lehmann 1990). Goldsmith et al. (1995) argue that innovative behavior is the most concrete manifestation of consumer innovativeness.

Product newness (radical vs. incremental)

Radically new products are innovations that embody a new technology that results in a new market infrastructure (O'Connor 1998; Schmidt and Calantone 1998). Radically new products create substantial discontinuity for consumers (Garcia and Calantone 2002) because they are completely new. Conversely, incrementally new products provide new features, benefits, or improvements in the existing technologies and do not result in major discontinuities for the consumer (Garcia and Calantone 2002).

Product complexity (complex vs. simple)

Product complexity is the extent to which consumers perceive the product as difficult to use (Rogers 1995). A product that offers many options or involves a large number of steps to use is typically perceived as complex (Burnham et al. 2003). Consumers are likely to perceive greater risk when purchasing complex new products because of the difficulty in understanding the product and how to use it, 
which leads to uncertainty and an increase in perceptions that a negative outcome might occur (Holak and Lehmann 1990). Similarly, the large number of attributes involved makes the gathering of information and evaluation of alternatives difficult (Shugan 1980).

Network externalities (present vs. absent)

Network externalities are the increase in the utility of a particular product that a consumer derives from using a good owing to the increase in the number of other agents consuming either that product or goods in conjunction with that product (Katz and Shapiro 1985). Consumers of technology products often prefer to purchase current technology upgrades and complementary products, rather than buying new technologies (Pae and Hyun 2002). Researchers have cited network externalities as one of the key driving forces behind this behavior (Song et al. 2009; Basu et al. 2003; Padmanabhan et al. 1997).

The two types of network externalities are direct and indirect. A direct network externality is the increase in the value associated with a product because additional users are in the network (Artle and Averous 1973). For example, the value of a telephone depends on the number of users connected to the telephone network. Conversely, an indirect network externality is the value attached to a product by the availability of complementary goods and services (Basu et al. 2003). For example, the value of a DVD player depends on the number of available DVD movie disks (Song et al. 2009).

Utilitarian versus expressive nature of the product

Products can also be classified as utilitarian or expressive according to consumers' motives for purchasing them (Dahlen and Bergendahl 2001). Utilitarian products are subject to cognitive motives, while expressive products are associated with affective motives. Consumers' purchase decisions for utilitarian products are mainly logical and objective and are based on utilitarian facts, such as inherent product features (Mittal 1988, 1989). Underlying the decision process for utilitarian products is a strong utilitarian need, and rational criteria are used (Dahlen and Bergendahl 2001). Examples of utilitarian products include detergents, headache remedies, and vacuum cleaners (Mittal 1989).

In contrast, the purchase of expressive products involves feelings and emotions. For expressive products, such as perfumes, designer clothes, and souvenirs, the physical performance of the product is less important (Mittal 1989). Instead, consumers focus on the expressive quality of the product, or the product's ability to express the user's personality, self-concept, or mood
(Mittal 1988). Thus, consumers are less susceptible to explicit information search, and if they find a particular image appealing and self-congruent, they develop a liking for the brand and purchase it (Holbrook and Hirschman 1982). When consumers purchase expressive products, although they may care about the product, they engage in less cognitive activity (Mittal 1988). Indeed, Mittal (1989) finds that consumers use more sources, make more extensive brand comparisons, and examine more brand features for utilitarian products than for expressive products.

\section{Development of research propositions}

Main effects

Past orientation and innovativeness Past orientation is characterized by self-control, risk aversion, and a general preference to buy familiar products. Baumeister et al. (1998) and Baumeister (2002) argue that people are likely to stick with their existing routines when they are in the habit of doing something. For example, buying groceries every Wednesday for several years leaves little room for impulsiveness (Baumeister 2002). This lack of spontaneity or impulsiveness leads past-oriented people to take less risk. Similarly, Cotte et al. (2004) find that women who are nostalgic avoid new or unfamiliar leisure activities and prefer doing familiar activities with which they grew up. Because the past ways of working provide a comfort zone (Holbrook 1993), these people hesitate to try new things. From a different perspective, past-oriented people find security in their habits, and thus they are hesitant to try new things and prefer to re-create and relive the past through the consumption of familiar goods and services (Braun-LaTour et al. 2007). Because consumer innovativeness involves changes in purchase and consumption patterns and therefore involves risk, past-oriented consumers, who are less likely to change, exhibit lower levels of innovativeness (Steenkamp et al. 1999).

$\mathrm{P}_{1}$ : Consumers with higher past orientation will exhibit lower levels of innovativeness.

Present orientation and innovativeness Present-oriented consumers have a high level of need for stimulation and seek products, information, and experiences that satisfy this need (Raju 1980). They also have less self-control to postpone their indulgence to a future period (Kivetz and Simonson 2002), and are less likely to think about the longterm implications of their actions (Hodgins and Engel 2002; Zimbardo and Boyd 1999). Instead, they are more interested in current stimulation through consumption. 
Baumeister and Heatherton (1996) note that when consumers are not able to resist current temptations, they tend to act impulsively and have little self-control. For such consumers, the unpleasantness of exerting control may seem too high, and the anticipated benefits may seem too small or remote. It is the anticipated regret or frustration of forgoing desired instant pleasure that prompts these consumers to give in to immediate temptations and act impulsively (Baumeister and Heatherton 1996).

According to Cotte et al. (2004), a hedonic and varietyseeking consumption ethic involves dealing with time as if it were a feast. They argue that people with such a time style perceive time as something to be consumed or taken advantage of, in pursuit of sensory pleasure and gratification. These consumers are not averse to taking risks to fulfill their hedonistic motives. Cotte et al. (2004) also find that in terms of shopping behavior, present-oriented consumers show a preference for novelty and a desire for variety. For example, they prefer novel grocery products and seek out a general variety of products and services. Thus, we argue that more present-orientated consumers are likely to be more innovative.

$\mathrm{P}_{2}$ : Consumers with higher present orientation will exhibit higher levels of innovativeness.

Future orientation and innovativeness Future-oriented people are driven by their goals, are achievement oriented, and do not hesitate to make short-term sacrifices for long-term gains (Murrell and Mingrone 1994; Strathman et al. 1994). Future-oriented people are well organized, focus constantly on their goals, and evaluate their actions according to the gains and losses pertaining to their future goals (Strathman et al. 1994; Kastenbaum 1961). In a related study, Nenkov et al. (2008) find that when people elaborate on potential future outcomes, they exhibit self-regulation when faced with a choice. Similarly, Baumeister and Heatherton (1996) argue that when consumers can transcend beyond the immediate stimuli to longer-term implications, they tend to be more self-controlled than otherwise. Furthermore, people with high future orientation are less risk taking (Lennings and Burns 1998; Zimbardo et al. 1997), do not take any actions that may jeopardize their future plans, and have a lower need for arousal (Raju 1980).

Developing this theorizing further, Cotte et al. (2004) identify "time as a map" as a metaphor of time style for those with a future temporal orientation. They find that future-oriented people are extremely involved consumers who spend time accumulating information, analyzing alternatives, and making thoughtful decisions. From a different perspective, future-oriented people may be interested in the new product if the innovation is likely to help them achieve their goals. However, at a broader level, we argue that future-oriented people are likely to be more deliberate and cautious than others as they tend to weigh the costs versus benefits of their actions, and are averse to taking risks that would jeopardize their future goals. Thus, they are less likely to be innovative.

$\mathrm{P}_{3}$ : Consumers with higher future orientation will exhibit lower levels of innovativeness.

Consumer innovativeness and innovative behavior The link between attitude and behavior is often explained by the theory of planned behavior (Ajzen 1991). The theory posits that people act in accordance with their behavioral intentions and perceptions of control over behavior (Ajzen 1991). Behavioral intentions are influenced by attitude toward the act, social norms, and perceived behavioral control. People first develop behavioral intentions on the basis of attitudes, and in turn the behavioral intentions influence behavior (in our model we do not explicitly show attitude $\rightarrow$ behavioral intention $\rightarrow$ behavior to achieve parsimony). This is consistent with prior research (e.g., Dempsey and Mitchell 2010; Wang et al. 2008; Stock and Hoyer 2005; Shrum et al. 1995). The stronger the behavioral intention, the more likely the behavior is likely to occur. Perceived behavioral control is the availability of time, money, and skills and the cooperation of others (Kang et al. 2006). The greater the perception of control over the behavior, the more likely the behavior is likely to occur.

The attitude-behavior relationship can also be explained using consistency theories, such as cognitive dissonance theory (Festinger 1957). This theory posits that people prefer to behave in a manner that does not create any inconsistency with their cognitions. According to Festinger (1957), inconsistency in cognition leads to psychological discomfort and motivates a person to attempt to restore cognitive consistency. For example, in the context of online shopping, consumers may have positive attitudes toward online purchasing. However, when they believe that significant referents think they should not purchase a product online, they may change their attitudes toward online purchasing to feel affiliated with the referent others (Taylor and Todd 1995). Thus, in general consumers want to avoid inconsistency and therefore exhibit behaviors consistent with their attitudes. By the same logic, consumers with high levels of innovativeness will try to be consistent and exhibit innovative behaviors, and those with low levels of innovativeness will exhibit innovative behaviors to a lesser extent.

In the current context, most studies find the relationship between consumer innovativeness and innovative behavior to be significant. For example, Steenkamp and Van Trijp (1996) find significant correlations between innate innovativeness and the possession of 46 new products. Similarly, 
Roehrich (1995) finds a significant relationship between innovativeness and the number of new products purchased. Likewise, Goldsmith et al. (1995) find significant correlations between domain-specific innovativeness and innovative behavior. In the context of Internet purchases, Goldsmith (2001) finds that domain-specific innovativeness has a significant correlation with Web usage, music downloading, and online purchasing. In addition, Goldsmith (2000) finds significant correlations between consumers' domain-specific innovativeness and their wine usage. Vandecasteele and Geuens (2010) find that motivational consumer innovativeness successfully predicts buying intentions for new products. However, with reference to food products, Foxall (1988) finds that consumer innovativeness is not related to the number of new products owned.

Thus, in line with the theory of planned behavior, cognitive dissonance theory, and the predominant empirical findings in the literature, we propose the following:

$\mathrm{P}_{4}$ : Consumers with higher levels of innovativeness will exhibit higher levels of innovative behavior.

\section{Moderating effects}

We next develop propositions that delineate the moderating roles of product newness, product complexity, network externalities, and the utilitarian versus expressive nature of the product on the main effect propositions developed previously. For ease of exposition and to provide clarity, when developing research propositions, we discuss these product characteristics as though they are categorical and dichotomous variables (e.g., a product is either a utilitarian new product or an expressive new product; the product is either complex or simple). However, our conceptual arguments for the propositions, the implications of the propositions, and the future empirical testing of the propositions are not restricted to such a classification, and they can be similarly applied if the variables are conceptualized as continuous. For example, products can be visualized as occupying specific locations on a complexity continuum, and the concept of a complex versus simple product can easily be translated into high complexity or low complexity. Similar arguments apply for the other three characteristics as well (i.e., products that are more radically innovative than incrementally innovative, products with more network externalities than less network externalities, and products that are more utilitarian than less utilitarian).

Newness of the product (radical vs. incremental) Companies strive to create radically new products in the pursuit of generating competitive advantage because these products supersede the current competition in the category in which they are launched (Christensen 1997). Consumers are not familiar with the radically new technology of the product and thus must be educated about the new technology and finally adopt the product (Von Hippel 1986). Incrementally new products require relatively less consumer learning and education because there is a level of comfort and familiarity with the technology (Von Hippel 1986). Because radically new products are perceived as very "new," they present higher levels of risk. Thus, they entail more consideration of costs and benefits than incremental innovations (Heiskanen et al. 2007). In contrast, incrementally new products provide a safer alternative/choice with lower levels of perceived risk.

The consumer's time orientation and the extent of newness of the product overlap in terms of the perceived risk. By their very nature, radically new products are newer, more different, and riskier than incrementally new products. Similarly, consumers with a past, present, and future orientation vary in terms of risk preference. As a consequence of this overlap, the effect of the three time orientations on consumer innovativeness varies depending on the newness of the product. For example, for presentoriented consumers, the positive effect of present orientation on consumer innovativeness should be greater for radically new products than for incrementally new products. Conversely, future-oriented consumers are cautious and do not indulge in high-risk propositions; thus, the negative effects of future orientation on consumer innovativeness should be greater for radically new products than for incrementally new products. Finally, past-oriented consumers are hesitant to change, and because radically new products present a high degree of change, the negative effect of past orientation on consumer innovativeness should be greater for radically new products than for incrementally new products.

$\mathrm{P}_{5}$ : The negative relationship between consumers' past orientation and their innovativeness is stronger for radically new products than for incrementally new products.

$\mathrm{P}_{6}$ : The positive relationship between consumers' present orientation and their innovativeness is stronger for radically new products than for incrementally new products.

$\mathrm{P}_{7}$ : The negative relationship between consumers' future orientation and their innovativeness is stronger for radically new products than for incrementally new products.

According to the theory of planned behavior, attitudes influence behaviors by affecting behavioral intention first. Petty et al. (1983) find that consumers who are more involved with a product show greater attitude-intention consistency than consumers who are less involved. Consis- 
tent with these findings, Kokkinaki and Lunt (1997) find that involvement increases the impact of attitudes on product choices.

Consistent with these arguments, we contend that the strength of the attitude-behavior relationship differs between radically and incrementally new products because these two types of products vary in the level of consumer involvement. When evaluating radically new products, consumers must enhance their knowledge and learn details about the product and the way it operates (Garcia and Calantone 2002; Von Hippel 1986). Therefore, radically new products have higher levels of consumer involvement. In contrast, for incrementally new products, the amount of learning is relatively less because consumers are more familiar with the technology related to incrementally new products than radically new products. Thus, we propose the following:

$\mathrm{P}_{8}$ : The positive relationship between consumers' innovativeness and innovative behavior is stronger for radically new products than for incrementally new products.

Complexity of the product (complex versus simple) Purchase of complex new products involves an increase in the number of new skills or scripts that must be learned when the new product is purchased. Consequently, as complexity increases, more consumer efforts are required to establish a relationship with the new product (Burnham et al. 2003). Thus, when consumers perceive new products as more complex, they perceive higher procedural switching costs and greater perceived risk. In contrast, less complex new products have fewer options and involve fewer steps in their use; therefore, they are perceived as having lower switching costs and lower perceived risk.

Past-oriented people seek comfort in the pleasant memories of the past and are happy in their set ways (Zimbardo and Boyd 1999); thus, they tend to experience a low need for change and are averse to taking risks. Because complex new products involve higher levels of consumer perceived risk in adopting new products, we argue that the negative effect of past orientation on consumer innovativeness is greater for complex new products. Similarly, futureorientated people tend to focus on their future goals and evaluate benefits and losses of their actions (Strathman et al. 1994); thus, they tend to be more cautious and risk averse than people who are not future oriented. As the risk and uncertainty involved is greater for complex new products, a person's future orientation has a greater negative impact on consumer innovativeness. Present-oriented consumers are engrossed in the thrill of the moment, focus on short-term gratifications (Murrell and Mingrone 1994), and are prone to taking risks. Because product complexity increases perceived risk associated with new products, the positive effects of present orientation on consumer innovativeness should be enhanced.

$\mathrm{P}_{9}$ : The negative relationship between consumers' past orientation and their innovativeness is stronger for complex new products than for simple new products.

$\mathrm{P}_{10}$ : The positive relationship between consumers' present orientation and their innovativeness is stronger for complex new products than for simple new products.

$\mathrm{P}_{11}$ : The negative relationship between consumers' future orientation and their innovativeness is stronger for complex new products than for simple new products.

As mentioned previously, according to the theory of planned behavior, behaviors are determined by intention and perceived behavioral control. In turn, behavioral intention is determined by attitude. Furthermore, the attitude-intention link is stronger when consumers are more involved. We contend that consumers are more involved in purchasing complex new products than purchasing simple products because doing so entails greater perceived risk, more cognitive processing by gathering and evaluating information, and more learning of new skills (Burnham et al. 2003; Holak and Lehmann 1990; Shugan 1980). Consequently, when consumers purchase complex new products, their attitudes are likely to be more consistent with their behavioral intentions. In contrast, for simple new products, the level of consumer involvement is lower, and therefore consumers' attitudes are less likely to be consistent with behavioral intention. Thus, we propose the following:

$\mathrm{P}_{12}$ : The positive relationship between consumers' innovativeness and innovative behavior is stronger for complex new products than for simple new products.

Network externalities of the product So important are network externality considerations for some customers that not only do they influence repeat purchase, upgrades, and purchase of complementary products, but they also drive initial purchase decisions (Shapiro and Varian 1999). Consumers often purchase a particular technology with a high market share because they perceive it as popular and predominant and, therefore, of better quality. As the user base of a particular technology expands, the benefits of network externalities induce the consumer to remain with the current technology; as that happens, the uses of the technology often increase, and it then becomes feasible to use that technology in other areas as well (Pae and Hyun 2002).

A major benefit associated with network externalities is the consumer's reduced uncertainty and risk in terms of 
availability of future product versions, upgrades, and complementary products and services (Padmanabhan et al. 1997). In addition, because many consumers infer the quality of a product from the number of users, the installed user base acts as a signal of product quality, further alleviating perceived psychological risks of product adoption (Padmanabhan et al. 1997). A larger user population means that there are more opportunities to share information, support, and content with others (Watanabe and Hobo 2004). Prior research has also found that when consumers know that network externalities exist, they are more likely to influence their friends and relatives to adopt the product (Redmond 1991) than when network externalities are absent.

Network externalities tend to diminish consumers' uncertainty and perceived risk in adopting new products. Therefore, because past orientation is associated with a low need for change and aversion to risk taking, we argue that the negative effect of past orientation on consumer innovativeness is lower when consumers know that there are network externalities. Similarly, future orientation is also associated with caution and risk aversion. Therefore, the negative effect of future orientation on consumer innovativeness tends to be lower with network externalities. Lastly, present-oriented consumers like to take risks, act impulsively, and are not known to make cautious, wellthought-out decisions. Therefore, we postulate that the moderating effects of network externalities on the relationship between present orientation and innovativeness further depend on how much the consumer deliberates on the benefits of the network externalities presented by the new product. When present-oriented consumers recognize the benefits of network externalities, the positive effects of present orientation on consumer innovativeness are enhanced when there are network externalities. In summary, we present the following propositions:

$\mathrm{P}_{13}$ : The negative relationship between consumers' past orientation and their innovativeness is weaker when the new product has network externalities than when it does not.

$\mathrm{P}_{14}$ : When consumers recognize the benefits of network externalities, the positive relationship between consumers' present orientation and their innovativeness is stronger when the new product has network externalities than when it does not.

$\mathrm{P}_{15}$ : The negative relationship between consumers' future orientation and their innovativeness is weaker when the new product has network externalities than when it does not.

The presence of network externalities helps reduce the perceived risk and uncertainty associated with the new product (Padmanabhan et al. 1997) because more people use/buy the product compared to a product without network externalities. Their presence also enhances the perception that the company will offer better support services as more people buy the product, resulting in greater perceived behavioral control (Watanabe and Hobo 2004; Shapiro and Varian 1999). Thus, the effect of consumer innovativeness on innovative behavior is likely to be greater for products with network externalities because consumers perceive less risk and greater control. In contrast, when no network externalities are associated with the new product, consumers are likely to determine that adoption is more risky with less control. Therefore, the effect of consumer innovativeness on innovative behavior is subdued. In light of these arguments, we offer the following proposition:

$\mathrm{P}_{16}$ : The positive relationship between consumers' innovativeness and innovative behavior is stronger for new products with network externalities than for those without network externalities.

Utilitarian versus expressive nature of the product We argued previously that there is a negative relationship between past orientation and consumer innovativeness (Steenkamp et al. 1999). Extant literature reveals that past-oriented people seek comfort in pleasant memories of the past (Holbrook 1993), and tend to choose products and services that make them nostalgic (Braun-LaTour et al. 2007). This implies that past orientation is determined more by emotional reasons than by utilitarian ones. Because expressive new products involve "feel" products and utilitarian new products involve "think" products, we argue that consumers' past orientation has a stronger effect on consumer innovativeness for expressive new products than for utilitarian new products.

Present-oriented people live for the moment and do not think of the long-term implications of their actions (Baumeister 2002; Zimbardo et al. 1997). They tend to make impulsive decisions when purchasing products and have less self-control. For example, Bergadaa (1990) finds that when given a set of options, present-oriented people tend to make hedonistic and emotional choices when choosing holiday options. Because present orientation and expressive new products overlap in terms of emotion and self-control, we argue that present orientation has a greater positive impact on consumer innovativeness for expressive new products than for utilitarian new products.

Future-oriented people are well organized, focus on their goals, and evaluate the gains and losses of their actions in terms of their future goals (Strathman et al. 1994). Because consumers buying utilitarian products tend to evaluate product features and use a rational decision process (Ratchford 1987; Vaughn 1986), future orientation is more 
consistent with the purchase of utilitarian new products than expressive new products. Therefore, we propose the following:

$\mathrm{P}_{17}$ : The negative relationship between consumers' past orientation and their innovativeness is stronger for expressive new products than for utilitarian new products.

$\mathrm{P}_{18}$ : The positive relationship between consumers' present orientation and their innovativeness is stronger for expressive new products than for utilitarian new products.

$\mathrm{P}_{19}$ : The negative relationship between consumers' future orientation and their innovativeness is stronger for utilitarian new products than for expressive new products.

According to Ajzen (1991), following the theory of planned behavior, the weight of each belief (i.e., attitude, subjective norm, and perceived behavioral control) in influencing a person's behavioral intention may vary depending on the nature of the behavior under investigation. The affective primacy hypothesis establishes that how people feel about the psychological objects determines their attitude (Zajonc 1980). Building on this thesis, in their feelings-as-information model, Winkielman et al. (1997) assert that affective evaluations are unaffected by higherorder cognitive processes. However, this does not rule out lower-level cognitive processes, which may also determine attitudes (Ajzen 2001). In purchasing expressive products (compared to purchasing utilitarian products), consumers base their purchase decisions more on emotions and engage less in cognitive activity. Conversely, consumers use cognitions relatively more for utilitarian new products (compared to expressive products), comparing brands and examining brand features more extensively (Mittal 1988). Thus, because consumers' disposition for expressive new products is driven mainly by affect and less by cognitive evaluations, the effect of consumer innovativeness on innovative behavior is likely to be greater than for utilitarian new products.

$\mathrm{P}_{20}$ : The positive relationship between consumers' innovativeness and innovative behavior is stronger for expressive new products than for utilitarian new products.

\section{Higher order moderating effects}

In the propositions developed above, we present the moderating effects of the four product characteristics $\left(\mathrm{P}_{5}-\mathrm{P}_{20}\right)$ considered one at a time. Products can be further classified by considering two product characteristics at a time. For example, products can be classified as radically new complex (simple) products, incrementally new com- plex (simple) products when considering the two characteristics of new product newness and complexity. We can obtain important insights by considering two such characteristics at a time. We present a method by which expectations of the effects of time orientation on consumer innovativeness and the effects of consumer innovativeness on innovative behavior can be derived when considering two product characteristics at a time.

Figure 2 helps develop propositions for new products classified on the basis of whether the new product is radically or incrementally new and whether the product is utilitarian or expressive. Based on $\mathrm{P}_{5}$, the effect of past orientation on consumer innovativeness is stronger for radically new products than for incrementally new products. Similarly, based on $\mathrm{P}_{17}$, the effect of past orientation on consumer innovativeness is stronger for expressive products than for utilitarian products. Based on $\mathrm{P}_{5}$ and $\mathrm{P}_{17}$ as seen in Fig. 2, the effect of past orientation on consumer innovativeness is strongest for expressive radically new product and the weakest for utilitarian incrementally new products. Therefore the following propositions (derivative of our previous propositions) can be derived.

$\mathrm{P}_{\mathrm{A}}$ : The negative relationship between past orientation and consumer innovativeness is stronger for expressive radically new products as compared to utilitarian incrementally new products, expressive incrementally new products, and utilitarian radically new products.

$\mathrm{P}_{\mathrm{B}}$ : The negative relationship between past orientation and consumer innovativeness is stronger for expressive incrementally new and utilitarian radically new products as compared to utilitarian incrementally new products.

A similar analysis can be conducted to combine the insights from $\mathrm{P}_{8}$ and $\mathrm{P}_{20}$ to understand the combined role of product innovativeness and the utilitarian or expressive nature of the product on the link between consumer innovativeness and innovative behavior. These propositions are presented below.

$\mathrm{P}_{\mathrm{C}}$ : The positive relationship between consumer innovativeness and innovative behavior is stronger for expressive radically new products as compared to utilitarian incrementally new products, expressive incrementally new products, and utilitarian radically new products.

$\mathrm{P}_{\mathrm{D}}$ : The positive relationship between consumer innovativeness and innovative behavior is stronger for expressive incrementally new and utilitarian radically new products as compared to utilitarian incrementally new products.

Similar propositions can be derived using the other combinations of product characteristics taken two at a time. Extending this conceptualization further, higher order 


\begin{tabular}{|c|c|c|}
\hline Effect of Past Orientation & $\begin{array}{c}\text { Expressive Product } \\
\mathrm{P}_{17}: \text { Stronger negative effect }\end{array}$ & $\begin{array}{c}\text { Utilitarian Product } \\
\mathrm{P}_{17}: \text { Weaker negative effect }\end{array}$ \\
\hline $\begin{array}{c}\text { Radically New Product } \\
\mathrm{P}_{5}: \text { Stronger negative effect }\end{array}$ & $\begin{array}{c}\text { Strongest effect: Expressive } \\
\text { radically new product }\end{array}$ & $\begin{array}{c}\text { Moderate effect: Utilitarian } \\
\text { radically new product }\end{array}$ \\
\hline $\begin{array}{c}\text { Incrementally New Product } \\
\mathrm{P}_{5}: \text { Weaker negative effect }\end{array}$ & $\begin{array}{c}\text { Moderate effect: Expressive } \\
\text { incrementally new product }\end{array}$ & $\begin{array}{c}\text { Cell \#3 } \\
\text { increment effect: Utilitarian } \\
\text { incremew product }\end{array}$ \\
\hline
\end{tabular}

Fig. 2 Example of combined moderating effects of product newness and utilitarian/expressive nature of product

interactions involving three or more product characteristics can be similarly examined. For example, a product could be low on complexity, radically new, and expressive. Propositions depicting the interaction effects of three or more product characteristics are not discussed here because they are beyond the scope of this research. As conceptual research and empirical examination of the propositions advanced here are carried out, they will pave the way for a fine-tuned understanding of the higher order interaction effects.

\section{Discussion}

The objectives of this research were to (1) investigate the relationship between past, present, and future time orientation and consumer innovativeness; (2) study the relationship between consumer innovativeness and innovative behavior; and (3) explore how the characteristics of a new product (radically vs. incrementally new products, new products with or without network externalities, complex vs. simple new products, and utilitarian vs. expressive new products) moderate the relationship between the three time orientations and consumer innovativeness and between innovativeness and innovative behavior. We next describe how our framework contributes to theory development, provides insights for managers, describes guidelines for empirical testing of the propositions, and explores avenues for future research.

Implications for theory development

The three types of time orientation and consumer innovativeness Prior research has argued that time orientation is fundamental to the consumer's personality and exerts a dynamic influence on his or her decision and actions (D'Alessio et al. 2003). To the best of our knowledge, this study is the first to conceptualize how the three time orientations (past, present, and future) influence consumer innovativeness. Although Steenkamp et al. (1999) find that nostalgia proneness has a negative effect on innovativeness, we evaluate time orientation holistically and study its effects on consumer innovativeness.
Relationship between consumer innovativeness and innovative behavior In the current context, most studies investigating the relationship between consumer innovativeness and innovative behavior find a significant relationship (e.g., Citrin et al. 2000; Goldsmith et al. 1995). In response to Roehrich's (2004) call for additional research probing the effects of new product characteristics while studying consumer innovativeness, our current inquiry assesses how new product characteristics moderate the link between consumer innovativeness and innovative behavior.

The moderating role of new product characteristics Our framework proposes that the effect of the three time orientations on consumer innovativeness and the relationship between consumer innovativeness and innovative behavior depend on the new product's characteristics. These propositions are new to the consumer innovativeness literature and build on the work of researchers, such as Goldsmith and Hofacker (1991).

In summary, our research contributes to the existing literature in several ways. First, we present new vital personality variables (past, present, and future time orientations) in the nomological network of consumer innovativeness. Second, we build on existing research on the importance of studying consumer innovativeness by adding the moderating roles of new dimensions of interest - namely, radical versus incremental new products, complex versus simple new products, new products with or without network externalities, and utilitarian versus expressive nature of the new product. Although these variables frequently occur in academic literature, the context of the current research makes them relevant and crucial to consumer innovativeness research. Third, we reinforce extant research on the consumer innovativeness-behavior link, offer new explanations and boundary conditions, and relate them to the moderating role of product characteristics.

\section{Managerial implications}

Our conceptual framework and the resulting propositions have several managerial implications that pertain to firms' marketing strategies for new products, as well as the 
consequences of consumer innovativeness and behavior on firm performance. First, a fine-tuned understanding of consumer innovativeness, along with our focal antecedent (time orientation), would provide guidelines for segmenting and targeting consumers and crafting messages in advertising campaigns. Our framework implies that new product characteristics should be considered along with the antecedent factors of consumer innovativeness to determine potential early adopters and the time orientation-related messages that would appeal to them.

Second, innovative behavior is clearly related to the timing and extent of new product adoptions and their subsequent use, and therefore it is related to customers' lifetime value. Our framework implies that consumers with varying levels of time orientation have different levels of consumer innovativeness and innovative behavior, and therefore they are likely to differ in profitability in both the short run and the long run. Although we did not consider firm profitability a key variable, our framework suggests that different segments of customers should be identified and different messaging strategies should be used for those segments.

Third, given that product characteristics constitute important boundary conditions for consumer innovativeness as well as its link with innovative behavior, companies should bundle different products to enhance the synergies among products in facilitating their adoption. For example, would bundling a radically new product with a simple product with many network externalities be successful? When combining products to form bundles, which factors work synergistically and which factors work cannibalistically?

\section{Empirical testing of the propositions}

Table 1 presents measurement items from the existing literature to provide a starting point for the empirical testing of the propositions advanced herein. Past orientation, present orientation, future orientation, consumer innovativeness, and innovative behavior are individualspecific characteristics that must be measured using selfreport multi-point scales. However, the levels of product characteristics may be determined externally (e.g., a product is either hedonic or utilitarian, or either simple or complex) or assessed based on consumer perception (e. g., perception of network externality). Thus, characteristics of each of the product categories can be visualized as a continuous scale (e.g., complexity ranging from very low to very high) or as categorical scale (e.g., a product is either utilitarian or expressive). The propositions can be tested by collecting data using the survey research method. We illustrate the method for testing propositions using a part of our model. This procedure can be generalized to other hypotheses. For example, for testing the propositions related to past orientation, product complexity, and consumer innovativeness, in the case of research using continuous variables, a regression equation along the following lines can be estimated (terms that are not relevant for this discussion are omitted for the sake of exposition).

Consumer_Innovativeness $=\beta_{0}+\beta_{1}{ }^{*}$ Past_Orientation $+\beta_{2}$

$$
\text { *Past_Orientation*Complexity }
$$

In this scenario, $P_{1}$ will be supported if $\beta_{1}$ is negative and $\mathrm{P}_{9}$ will be supported if $\beta_{2}$ is negative. The same approach applies when product complexity is measured as a categorical variable (either measured directly as a categorical variable or measured as a continuous variable and a method such as median split is used to form categories). We can also use an expanded version of Eq. (1) to test propositions involving two or more product characteristics along with a time orientation. Similarly, when product categories are treated as categorical, Eq. (1) can be estimated for the different levels of the second product characteristic.

A different procedure can also be used if both past orientation and complexity are treated as categorical variables. Table 2 shows how the means of the various groups can be organized. $\mathrm{P}_{1}$ will be supported if Cell 7 is greater than Cell 8. $\mathrm{P}_{9}$ will be supported if (Cell 2-Cell 4) is greater than (Cell 1-Cell 3). These differences in means can be evaluated using t-tests after conducting an ANOVA.

While the above procedures deal with testing one time orientation at a time, a comprehensive model including the effect of all three time orientation on consumer innovativeness and innovative behavior can be tested using structural equation modeling. The significance of individual paths can be used to test the direct effects of the three time orientations. Propositions related to the effects of product characteristics can be tested using multi-group analysis, where groups are formed based on the levels of each product characteristic. The difference in the unstandardized coefficients can be used to test the hypotheses involving product characteristics.

Table 2 Illustration of empirical testing of the propositions

\begin{tabular}{llll}
\hline & Complexity low & Complexity high & Total \\
\hline Past orientation low & Cell 1 & Cell 2 & Cell 7 \\
Past orientation high & Cell 3 & Cell 4 & Cell 8 \\
Total & Cell 5 & Cell 6 & Cell 9 \\
\hline
\end{tabular}


Future research agenda

We hope that this research acts as a springboard for future research to understand the antecedents and consequences of consumer innovativeness and its boundary conditions. We delineate some useful avenues for future research next.

Time orientation, consumer innovativeness, and behavior Careful research is needed to empirically test the research propositions advanced herein. Although survey-based research may support this investigation, experimental research backed by longitudinal studies would shed more light on this subject. Future studies also could track actual consumer purchase (using scanner data) of new products in the market and correlate it with the predominant time orientation measures collected for consumers.

Our conceptual framework concentrates on the moderating effect of product characteristics. In the future, propositions related to the mediating processes by which the three time orientations impact consumer innovativeness should also be addressed. The inclusion of mediating variables would add to the development of a more complete theoretical network. The conceptual support for the propositions in our framework is based on the notion that the level of risk aversion and self-control differs among people with high and low levels of each of the three time orientations. Other possible explanations, such as differences in people's optimum stimulation level (Raju 1980), could be used to provide support for the propositions. Conceptually, future studies could evaluate which of these mediating variables are relatively more important than others. For example, does present orientation affect self-control more than future and past orientation? In other words, does self-control have a stronger mediating role in the present orientation-consumer innovativeness link? Is this mediation stronger for certain types of products (e.g., complex vs. simple products)? Similarly, the varying levels of mediation for the other time orientations, as well as the role of the product category, could be investigated.

Moderating role of product characteristics Our study focused on the moderating role of product characteristics in influencing the relationship between time orientation and innovativeness and between innovativeness and behavior. It may be worthwhile also to examine whether the relative influence of the three time orientations varies depending on the nature of the product. For example, is the impact of present orientation on consumer innovativeness greater than the impact of future and past orientation, and if so, why? Under what conditions is the impact of one time orientation stronger than the others? For example, for expressive products, is the role of present orientation relatively stronger, or for radically new products, is the effect of future orientation on consumer innovativeness stronger? These questions present fertile grounds for future research and would expand our knowledge base.

Other factors related to consumer innovativeness The role of other contextual and motivational factors in reducing or enhancing the effects of time orientation on consumer innovativeness and the effects of consumer innovativeness on behavior should be investigated. Examples of such factors include brand-level factors, consumer characteristics, and cultural factors in international markets. First, for brand-level factors, brand characteristics such as positioning and price (Atuahene-Gima 2005; Chandy and Tellis 2000) may influence the adoption of a new brand. In other words, is the adoption behavior likely to be different for a music player launched by Apple than for one launched by another company, and if so, how? Do brand characteristics have a moderating role or a direct role in influencing consumer innovativeness? These questions suggest a potential investigation of a brand-specific innovativeness concept, which would capture aspects of innovativeness that are not addressed in domain-specific innovativeness.

Second, the role of consumer characteristics, including demographics (e.g., age, income) and psychological variables (e.g., consumer expertise, need for uniqueness, need for cognition), could also be investigated. Third, with the advent of globalization, the role of culture has become ubiquitous. One of Hofstede's (1980) culture dimensions is long-term orientation. How does this cultural dimension relate to time orientation? Are there other cultural dimensions that directly or indirectly influence consumer innovativeness, innovative behavior, and/or the link between them?

Scope of innovative behavior Although in this study we conceptualize innovative behavior as adoption of new products, innovative behavior can have different dimensions, including speed of adoption (when), extent of use when adopted (how much), purchase of follow-up products/ services (e.g., iTunes after iPhone), and the propensity to adopt newer version of the same basic product in the future (e.g., subsequent versions of iPhone). Such an in-depth investigation is the logical next step in further advancing this research domain.

\section{Conclusion}

With the increasing importance of innovation for the competitive advantage of organizations and the role of consumer innovativeness in the successful introduction and 
adoption of new products in the marketplace, our framework, which examines the link among time orientation, consumer innovativeness, innovative behavior, and product characteristics, helps advance understanding of consumer behavior and offers guidelines for managers. We hope that other researchers will continue to conduct research in this exciting domain.

\section{References}

Ajzen, I. (1991). The theory of planned behavior: Some unresolved issues. Organizational Behavior and Human Decision Processes, $50(2), 179-211$.

Ajzen, I. (2001). Nature and operation of attitudes. Annual Review of Psychology, 52(February), 27-58.

Artle, R., \& Averous, C. (1973). The telephone system as a public good: Static and dynamic aspects. Bell Journal of Economics and Management Science, 4(1), 89-100.

Atuahene-Gima, K. (2005). Resolving the capability-rigidity paradox in new product innovation. Journal of Marketing, 69(1), 61-85.

Barczak, G., Griffin, A., \& Kahn, B. K. (2009). Trends and drivers of success in NPD practices: Results of the 2003 PDMA best practices study. Journal of Product Innovation Management, 26 (1), 3-23.

Bartels, J., \& Reinders M. J. (2010). Consumer innovativeness and its correlates: A propositional inventory for future research. Journal of Business Research. Retrieved November 15, 2010 from doi:10.1016/J.Jbusres.2010.05.002,accessedon

Basu, A., Mazumdar, T., \& Raj, S. P. (2003). Indirect network externality effects on product attributes. Marketing Science, 22 (2), 209-221.

Baumeister, R. F. (2002). Yielding to temptation: Self-control failure, impulsive purchasing, and consumer behavior. Journal of Consumer Research, 28(6), 670-676.

Baumeister, R. F., \& Heatherton, T. F. (1996). Self-regulation failure: An overview. Psychological Inquiry, 7(1), 1-15.

Baumeister, R. F., Bratlavsky, E., Muraven, M., \& Tice, D. M. (1998). Ego depletion: Is the active self a limited resource? Journal of Personality and Social Psychology, 74(5), 1252-1265.

Baumgartner, H., \& Steenkamp, J.-B. (1996). Exploratory consumer buying behavior: Conceptualization and measurement. International Journal of Research in Marketing, 13(2), 121-137.

Bello, D., Chelariu, C., \& Zhang, L. (2003). The antecedents and performance consequences of relationalism in export distribution channels. Journal of Business Research, 56(1), 1-16.

Bergadaa, M. M. (1990). The role of time in the action of the consumer. Journal of Consumer Research, 17(3), 289-302.

Braun-Latour, K. A., Latour, M. S., \& Zinkhan, G. M. (2007). Using childhood memories to gain insight into brand meaning. Journal of Marketing, 71(3), 45-60.

Burnham, T. A., Frels, J. K., \& Mahajan, V. (2003). Consumer switching costs: A typology, antecedents, and consequences. Journal of the Academy of Marketing Science, 31(2), 109-126.

Chandy, R. K., \& Tellis, G. J. (2000). The incumbent's curse? incumbency, size, and radical product innovation. Journal of Marketing, 64(3), 1-17.

Christensen, C. M. (1997). The innovator's dilemma: When new technologies cause great firms to fail. Boston: Harvard Business School.

Citrin, A. V., Sprott, D. E., Silverman, S. N., \& Stem, D. E., Jr. (2000). Adoption of internet shopping: The role of consumer innovativeness. Industrial Management and Data Systems, 100(7), 294-300.
Cooper, R. G., Edgett, S. J., \& Kleinschmidt, E. J. (2001). Portfolio management for new products. Cambridge: Perseus Books.

Cotte, J., Ratneshwar, S., \& Mick, D. G. (2004). The time of their lives: Phenomenological and metaphorical characteristics of consumer timestyles. Journal of Consumer Research, 31(2), 333-345.

Crowley, A. E., Spangenberg, E. R., \& Hughes, K. R. (1992). Measuring the hedonic and utilitarian dimensions of attitudes toward product categories. Marketing Letters, 3(3), 239-249.

Dahlen, M., \& Bergendahl, J. (2001). Informing and transforming on the web: An empirical study of response to banner ads for functional and expressive products. International Journal of Advertising, 20(2), 189-205.

D'Alessio, M., Guarino, A., De Pascalis, V., \& Zimbardo, P. G. (2003). Testing Zimbardo's Stanford Time Perspective Inventory (STPI) - short form. Time and Society, 12(2/3), 333-347.

De Volder, M., \& Lens, W. (1982). Academic achievement and future time perspective as a cognitive-motivational concept. Journal of Personality and Social Psychology, 42(3), 566-571.

Dempsey, M. A., \& Mitchell, A. A. (2010). The influence of implicit attitudes on choice when consumers are confronted with conflicting attribute information. Journal of Consumer Research, $37(4), 614-625$.

Festinger, L. (1957). A theory of cognitive dissonance. Evanston: Row, Peterson.

Foxall, G. R. (1988). In E. C. Hirschman \& J. N. Seth (Eds.), Consumer innovativeness: Novelty-seeking, creativity, and cognitive style. Consumer behavior. Greenwich: JAI.

Garcia, R., \& Calantone, R. (2002). A critical look at technological innovation typology and innovativeness terminology: A literature review. Journal of Product Innovation Management, 19(2), 110-132.

Gatignon, H., \& Robertson, T. S. (1985). A propositional inventory for new diffusion research. Journal of Consumer Research, 11(4), 849-867.

Goldsmith, R. E. (2000). Identifying wine innovators: A test of the domain specific innovativeness scale using known groups. International Journal of Wine Marketing, 12(2), 37-46.

Goldsmith, R. E. (2001). Using the domain specific innovativeness scale to identify innovative internet consumers. Internet Research, 11(2), 149-156.

Goldsmith, R. E., \& Foxall, G. R. (2003). The measurement of innovations. In L. V. Shavinina (Ed.), International handbook on innovation. Oxford: Elsevier.

Goldsmith, R. E., Freiden, J. B., \& Eastman, J. K. (1995). The generality/specificity issue in consumer innovativeness research. Technovation, 15(10), 601-611.

Goldsmith, R. E., \& Hofacker, C. H. (1991). Measuring consumer innovativeness. Journal of the Academy of Marketing Science, 19 (3), 209-221.

Gonzalez, A., \& Zimbardo, P. G. (1985). Time in perspective. Psychology Today, 19(3), 21-26.

Harber, K. D., Zimbardo, P. G., \& Boyd, J. N. (2003). Participant selfselection biases as a function of individual differences in time perspective. Basic and Applied Social Psychology, 25(3), 255264.

Heiskanen, E., Hyvonen, K., Niva, M., Pantzar, M., Timonen, P., \& Varjonen, J. (2007). User involvement in radical innovation: Are consumers conservative? European Journal of Innovation Management, 10(4), 489-509.

Hirunyawipida, T., \& Paswan, A. K. (2006). Consumer innovativeness and perceived risk: Implications for high technology product adoption. Journal of Consumer Marketing, 23(4), 182-198.

Hodgins, D. C., \& Engel, A. (2002). Future time perspective in pathological gamblers. The Journal of Nervous and Mental Disease, 190(11), 775-780. 
Hoffman, S., \& Soyez, K. (2010). A cognitive model to predict domain-specific consumer innovativeness. Journal of Business Research, 63(7), 778-785.

Hofstede, G. (1980). Culture's consequences. Beverly Hills: Sage.

Holak, S. L., \& Lehmann, D. R. (1990). Intentions and the dimensions of innovation: An exploratory model. Journal of Product Innovation Management, 7(1), 59-73.

Holbrook, M. B. (1993). Nostalgia and consumption preferences: Some emerging patterns of consumer tastes. Journal of Consumer Research, 20(2), 245-256.

Holbrook, M. B., \& Hirschman, E. C. (1982). The experiential aspects of consumption: Consumer fantasies, feelings, and fun. Journal of Consumer Research, 9(3), 132-140.

Im, S., Bayus, B. L., \& Mason, C. H. (2003). An empirical study of innate consumer innovativeness, personal characteristics, and new-product adoption behavior. Journal of the Academy of Marketing Science, 31(1), 61-73.

Im, S., Mason, C. H., \& Houston, M. (2007). Does innate consumer innovativeness relate to new product/service adoption behavior? the intervening role of social learning via vicarious innovativeness. Journal of the Academy of Marketing Science, 35(1), 63-75.

Kang, H., Hahn, M., Fortin, D. R., Hyun, Y. J., \& Eom, Y. (2006). Effects of perceived behavioral control on the consumer usage intention of e-coupons. Psychology and Marketing, 23(10), 841-864.

Kastenbaum, R. (1961). The dimensions of future time perspective: An experimental analysis. The Journal of General Psychology, 65(2), 203-218.

Katz, M. L., \& Shapiro, C. (1985). Network externalities, competition and compatibility. The American Economic Review, 75(3), 424-440.

Keough, K. A., Zimbardo, P. G., \& Boyd, J. N. (1999). Who's smoking, drinking, and using drugs? time perspective as a predictor of substance use. Basic and Applied Social Psychology, 21(2), 149-164.

Kivetz, R., \& Simonson, I. (2002). Self-control for the righteous: Toward a theory of pre-commitment to indulgence. Journal of Consumer Research, 29(2), 199-218.

Kokkinaki, F., \& Lunt, P. (1997). The relationship between involvement, attitude accessibility and attitude-behaviour consistency. British Journal of Social Psychology, 36(4), 497-509.

Lennings, C., \& Burns, A. (1998). Time perspective: Temporal extension, time estimation, and impulsivity. Journal of Psychology, 132(4), 367-380.

Levine, R. (1997). A geography of time: The temporal misadventure of a social psychologist, or how every culture keeps time just a little bit differently. New York: Basic Books.

Martin, N. (2008). How habits undermine marketing. FT Press. Retrieved March 25, 2009 from http://www.ftpress.com/Articles/ Printerfriendly. Aspx?P=1223844

Mittal, B. (1988). The role of affective choice mode in the consumer purchase of expressive products. Journal of Economic Psychology, 9(4), 499-524.

Mittal, B. (1989). Must consumer involvement always imply more information search? In T. K. Srull (Ed.), Advances in consumer research. Provo: Association for Consumer Research.

Murrell, A., \& Mingrone, M. (1994). Correlates of temporal perspective. Perceptual and Motor Skills, 78(2), 1331-1334.

Nenkov, G., Jeffrey, Y., Inman, J., \& Hulland, J. (2008). Considering the future: The conceptualization and measurement of elaboration on potential outcomes. Journal of Consumer Research, 35(1), 126-141.

Nuttin, J. R. (1985). Future time perspective and motivation: Theory and research method. Hillsdale: Erlbaum.

O'Connor, G. (1998). Market learning and radical innovation: A cross case comparison of eight radical innovation projects. Journal of Product Innovation Management, 15(2), 151-167.
Padmanabhan, V., Rajiv, S., \& Srinivasan, K. (1997). New products, upgrades and new releases: A rationale for sequential product introduction. Journal of Marketing Research, 34 (4), 456-472.

Pae, J. H., \& Hyun, J. S. (2002). The impact of technology advancement strategies on consumers' patronage decisions. Journal of Product Innovation Management, 19(5), 375-383.

Paswan, A., \& Troy, L. (2005). An investigation of perceptual factors influencing consumer's intention to adopt radical versus incremental new products. American Marketing Association Conference Proceedings Vol. 16. K. Seiders, \& G. Voss (Eds.), Chicago: American Marketing Association

Petty, R. E., Cacioppo, J. T., \& Schumann, D. (1983). Central and peripheral routes to advertising effectiveness: The moderating role of involvement. Journal of Consumer Research, 10(2), 135-147.

Raju, P. S. (1980). Optimum stimulation level: Its relationship to personality, demographics and exploratory behavior. Journal of Consumer Research, 7(3), 272-282.

Ratchford, B. T. (1987). New insights about the FCB grid. Journal of Advertising Research, 27(4), 24-38.

Redmond, W. H. (1991). When technologies compete: The role of externalities in nonlinear market response. Journal of Product Innovation Management, 8(3), 170-183.

Roehrich, G. (1995). Innovativite 'SHe' Doniste Et Sociale: Proposition D'UneE'Chelle De Mesure. Research in Applied Marketing, $9(2), 19-41$

Roehrich, G. (2004). Consumer innovativeness concepts and measurements. Journal of Business Research, 57(6), 671-677.

Rogers, E. M. (1995). Diffusion of innovations. New York: Free.

Rogers, E. M., \& Shoemaker, F. (1971). Communication of innovations: A cross-cultural approach. New York: The Free.

Schmidt, J. B., \& Calantone, R. J. (1998). Are really new product development projects harder to shut down? Journal of Product Innovation Management, 15(2), 111-123.

Shapiro, C., \& Varian, H. R. (1999). Information rules: A strategic guide to the network economy. Boston: Harvard Business School.

Shrum, L. J., McCarty, J. A., \& Lowrey, T. (1995). Buyer characteristics of the green consumer and their implications for advertising strategy. Journal of Advertising, 24(2), 71-82.

Shugan, S. M. (1980). The costs of thinking. Journal of Consumer Research, 7(2), 99-111.

Song, M., Parry, M. E., \& Kawakami, T. (2009). Incorporating network externalities into technology acceptance model. Journal of Product Innovation Management, 26(2), 291-307.

Steenkamp, J.-B. E. M., \& Gielens, K. (2003). Consumer and market drivers of the trial probability of new consumer packaged goods. Journal of Consumer Research, 29(4), 368384.

Steenkamp, J.-B. E. M., Hofstede, F., \& Wedel, M. (1999). A crossnational investigation into the individual and national cultural antecedents of consumer innovativeness. Journal of Marketing, 63(2), 55-69.

Steenkamp, J.-B. E. M., \& Van Trijp, H. C. M. (1996). Task experience and validity in perceptual mapping: A comparison of two consumer-adaptive techniques. International Journal of Research in Marketing, 13(3), 265-277.

Stock, R. M., \& Hoyer, W. D. (2005). An attitude-behavior model of salespeople's customer orientation. Journal of the Academy of Marketing Science, 33(4), 536-552.

Strathman, A., Gleicher, F., Boninger, D., \& Edwards, C. S. (1994). The consideration of future consequences: Weighing immediate and distant outcomes of behavior. Journal of Personality and Social Psychology, 66(4), 742-752.

Taylor, S., \& Todd, P. (1995). Decomposition and crossover effects in the theory of planned behavior: A study of consumer adoption intentions. International Journal of Research in Marketing, 12(2), 137-155. 
Vandecasteele, B., \& Geuens, M. (2010). Motivated consumer innovativeness: Concept, measurement, and validation. International Journal of Research in Marketing, 27(4), 308318.

Vaughn, R. (1986). How advertising works: A planning model revisited. Journal of Advertising Research, 26(1), 57-61.

Von Hippel, E. (1986). Lead users: A source of novel product concepts. Management Science, 32(7), 791-805.

Voss, K. E., Spangenberg, E. R., \& Grohmann, B. (2003). Measuring the hedonic and utilitarian dimensions of consumer attitude. Journal of Marketing Research, 40(3), 310-320.

Wang, G., Dou, W., \& Zhou, N. (2008). Consumption attitudes and adoption of new consumer products: A contingency approach. European Journal of Marketing, 42(1/2), 238-254.
Watanabe, C., \& Hobo, M. (2004). Co-evolution between internal motivation and external expectation as a source of firm selfpropagating function creation. Technovation, 24(2), 109.

Winkielman, P., Zajonc, R. B., \& Schwarz, N. (1997). Subliminal affective priming resists attributional interventions. Cognition and Emotions, 11(4), 433-465.

Zajonc, R. B. (1980). Feelings and thinking: Preferences need no inferences. American Psychologist, 35(2), 151-175.

Zimbardo, P., Keough, A. K., \& Boyd, J. N. (1997). Present time perspective as a predictor of risky driving. Personality and Individual Differences, 23(6), 1007-1023.

Zimbardo, P., \& Boyd, J. N. (1999). Putting time in perspective: A valid, reliable individual-differences metric. Journal of Personality and Social Psychology, 77(6), 1271-1288. 